\title{
Endothelin, vasopressin, and substance P like immunoreactivity in cultured and intact epithelium from rabbit trachea
}

\author{
R E Rennick, A Loesch, G Burnstock
}

\begin{abstract}
Background The control of airways reactivity is essential to our understanding of disease processes such as asthma. Many studies have examined the neural control of the airways, but more recently there has been evidence to show that the epithelium lining the airways may influence airways reactivity.

Methods Rabbit tracheal epithelial cells were dispersed with enzymes, grown in primary culture and fixed. Tissue from intact tracheas was also sampled and fixed. Localisation of the vasoactive substances endothelin-1, arginine-vasopressin, and substance $P$ was investigated by immunolabelling techniques.

Results Scattered immunolabelling to endothelin-1, arginine-vasopressin, and substance $P$ was found throughout the cultures (with $<20 \%$ of cells staining positively to each antibody). At the ultrastructural level this immunoreactivity was found in the cytoplasmic matrix. In addition, immunoreactivity of intact tissue to endothelin-1, argininevasopressin, and substance $P$ was examined and positively staining cells were found to be scattered through the epithelium.

Conclusions The presence of these vasoactive substances within the epithelium lining the airways supports the view that epithelial cells may provide an additional mechanism in the control of airways reactivity.
\end{abstract}

(Thorax 1992;47:1044-1049)

Hyperreactivity of the airways is a characteristic feature of asthma. In such patients damage or loss of the airways epithelium is a common finding. ${ }^{1}$ The epithelium lining the airways was originally considered merely as a barrier preventing passage of dust, microorganisms, and other airborne particles into the underlying tissue. More recently, however, it has been shown that removal of the airways epithelium leads to increased responses of the smooth muscle of the airways to various contractile stimuli. ${ }^{2}$ This phenomenon occurs in the airways of a number of different species, including dog, guinea pig, rabbit, and man..$^{3-8}$ Studies by Flavahan and Vanhoutte ${ }^{9}$ showed that there was increased sensitivity of the airways to histamine, acetylcholine, and 5-hydroxytryp- tamine (5-HT) after removal of the epithelium. They suggested that this might indicate that an epithelium derived relaxing factor, analogous to the endothelium detived relaxing factor released from vascular endothelial cells, ${ }^{10}$ is active in the airways. Orehek et al examined the influence on airways reactivity of drugs inhibiting prostaglandin synthesis and their results suggested that release of products of the cyclooxygenase pathway may be responsible for airways relaxation. ${ }^{11}$

Since the early 1970 s it has been known that there are amine precursor uptake and decarboxylation (APUD) cells present in the airways epithelium. ${ }^{12}$ These cells are found throughout the airways in innervated groups, known as neuroepithelial bodies, but in the trachea they occur only as single cells. ${ }^{13}$ Studies using microspectrofluorometry have shown that these cells contain amines such as $5-\mathrm{HT} .{ }^{14}{ }^{15} \mathrm{It}$ is possible that other vasoactive substances that may influence airways reactivity are present within the airways epithelium. In this study, tracheal epithelial cells were isolated and cultured and the presence, in both isolated cells and intact tissue, of endothelin-1 (ET-1), arginine-vasopressin (AVP), and substance $P$ (SP) examined at the light and electron microscopic levels.

\section{Methods}

CELL CULTURE

Male New Zealand White rabbits aged 4-6 months were injected with a lethal dose of Sagatal (RMB Animal Health, Dagenham, UK) and exsanguinated. Tracheal epithelial cells were isolated by enzymatic treatment. ${ }^{16}$ Briefly, the trachea was removed under sterile conditions and placed in Hanks' Balanced Salt Solution (HBSS; Gibco/Life Technologies, Paisley, UK) supplemented with penicillin $\left(2 \times 10^{5}\right.$ units/1; Glaxo Laboratories, Greenford), cleaned of adherent muscle and connective tissue, then clamped at one end and filled with a solution of $0 \cdot 1 \%$ protease (Sigma, Poole, UK) in HBSS. The other end was clamped so that the tissue formed a sealed tube, and the tissue was then incubated overnight at $4^{\circ} \mathrm{C}$. The following morning the tissue was unclamped, the lumen washed thoroughly with HBSS, and the resulting suspension centrifuged at $100 \mathrm{~g}$ for 5 minutes. The resulting pellet was resuspended in HBSS and spun as above. The cells were resuspended in Ham's F12 media (Gibco) supplemented with 5\%

\footnotetext{
R2

Revised version received

8 June 1992

Accepted 18 June 1992

Department of

Developmental

for Neuroscience,

WC1E 6BT

A Loesch

Reprint requests to:

Professor Burnstock
} 
FCS (fetal calf serum; Gibco), glutamine (Gibco) and penicillin ( $1 \times 10^{5}$ units/1; Glaxo) and seeded directly into four-well multidishes (12 mm diameter; Gibco/Life Technologies, Uxbridge) for electron microscopy or into multidishes in which glass coverslips $(10 \mathrm{~mm}$ diameter) had been placed for histology.

\section{HISTOLOGY}

To confirm that the cells obtained from protease treatment of the trachea were epithelial, the cells were taken on days 3 or 4 of culture, fixed in $4 \%$ paraformaldehyde for one hour, washed in $80 \%$ ethanol and made permeable in Triton$\mathrm{X}-100$. The cells were then incubated with antibodies to smooth muscle myosin (the gift of Dr Groschel-Stewart), fibronectin (Dako, High Wycombe) or $\alpha$-keratin (Incstarr, Stillwall, Minnesota), then washed and incubated with swine antirabbit labelled fluorescein (Nordic, Tilberg, The Netherlands). The coverslips were mounted in Citifluor (Citifluor, London) and viewed under a Zeiss IIIRS microscope. In addition, the periodic acid Schiff (PAS) method for mucopolysaccharides was used to identify goblet cells. ${ }^{17}$

\section{CELLULAR ADHERENCE}

Tracheal epithelial cells were isolated as described above, counted with a haemocytometer, and seeded into culture. At 1, 2, 3, 4, 5, and 24 hours the supernatant was removed and $0.5 \mathrm{ml}$ of $0.5 \mathrm{~mol} / 1 \mathrm{NaOH}$ was added to the wells to solubilise the adherent cells. The protein content of each of the wells was then determined by the method of Lowry et al ${ }^{18}$ and compared with that of the whole cell suspension before plating.

\section{IMMUNOCYTOCHEMISTRY \\ Cell culture}

After 3-5 days in culture the cells were fixed for two hours at $4^{\circ} \mathrm{C}$ in $0.1 \mathrm{~mol} / 1$ phosphate buffer, $\mathrm{pH} 7 \cdot 4$, containing $4 \%$ paraformaldehyde, $0 \cdot 1-$ $0 \cdot 2 \%$ glutaraldehyde, $1 \cdot 8 \% \mathrm{DL}-$ lysine $\mathrm{HCl}$ and $0.2 \%$ sodium $m$-periodate. ${ }^{19}$ The cultures were then washed in buffer for three hours, incubated for 30 minutes in $0.3 \%$ hydrogen peroxide in methanol (to block endogenous peroxidases) and stored overnight at $4^{\circ} \mathrm{C}$ in $0.1 \mathrm{~mol} / 1$ Tris buffer, $\mathrm{pH} 7 \cdot 4$. The avidin-biotin-peroxidase complex (ABC) method ${ }^{20}$ was used for the localisation of ET-1, AVP, and SP in tracheal epithelial cells cultured on glass coverslips and in $12 \mathrm{~mm}$ diameter wells. The ABC Kit (Vectostain Elite Kit, Vector Laboratories, Peterborough) was used with $0.1 \mathrm{~mol} / 1$ Tris buffer for the immunoprocedure. The fixed cells were first incubated with normal goat serum (Nordic Immunology, Tilberg, The Netherlands) at a dilution of 1:50 for 30 minutes, washed in buffer for 15 minutes, then exposed overnight to polyclonal antisera for rabbit ET-1 (Cambridge Research Biochemicals, Cambridge), AVP (provided by Professor C J Johnston, Monash University, Melbourne, Australia), and SP (Cambridge Research Biochemicals, Cambridge) (dilutions 1:5001:2000). The cells were washed for 45 minutes, then incubated for 45 minutes, with the biotinylated second antibody. Following another wash (30 minutes), the cells were incubated with the $\mathrm{ABC}$ complex for 45 minutes, washed, then incubated with $0.05 \% 3^{\prime} 3^{\prime}$-diaminobenzidine (DAB; Sigma) in Tris for five minutes followed by incubation for 10 minutes with $0.05 \%$ DAB containing $0.01 \%$ hydrogen peroxide. The cells were then washed in Tris buffer, postfixed with $1 \%$ osmium tetroxide for 30 minutes, washed in buffer and dehydrated in a graded series of ethanol, followed by propylene oxide. Coverslips were then mounted on glass slides in Araldite for viewing under a Zeiss IIIRS light microscope.

For ultrastructural analysis of the immunostaining, cells were grown directly in $12 \mathrm{~mm}$ culture wells and treated as above. The samples were then exposed to propylene oxide and rapidly removed from the culture dish into Araldite resin. After polymerisation, sections were cut, stained with uranyl acetate and lead citrate, and examined with a Philips-300 electron microscope.

\section{Intact tissue}

The trachea was removed from 4-6 month old New Zealand White rabbits and fixed as described above for cultured cells. After fixation the trachea was divided into three levels (upper, medial, and lower) and frozen rings, $7 \mu \mathrm{m}$ thick, were cut on a Reichert-Jung Cryocut 1800 cryostat from each level of the trachea. The sections were then processed for detection of ET-1, AVP, and SP according to the same immunocytochemistry procedure described above. Specimens were postfixed with $0 \cdot 1 \%$ osmium tetroxide for 10 seconds, dehydrated in ethanol, embedded in mountant (BDH, Poole) and viewed under a Zeiss IIIRS light microscope.

\section{Controls}

A number of controls were used to determine the specificity of the immunolabelling at the light microscopic level. The primary antiserum and IgG steps respectively were omitted. In addition, normal goat serum and normal rabbit serum (Nordic) (dilution 1:500-2000) were substituted for antisera to ET-1 and AVP. Control preabsorptions of the above antisera (24 hours at $4^{\circ} \mathrm{C}$ ) with synthetic human ET-1, synthetic AVP, and synthetic SP (all from Cambridge Research Biochemicals) inhibited immunostaining.

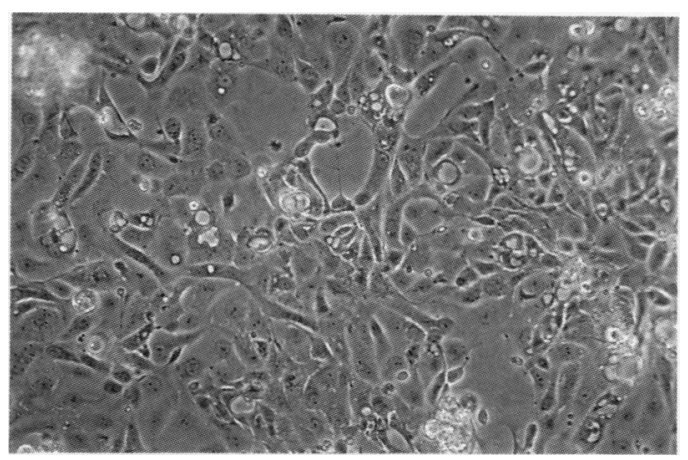

Figure 1 Phase contrast micrograph of rabbit tracheal epithelial cells in culture. 


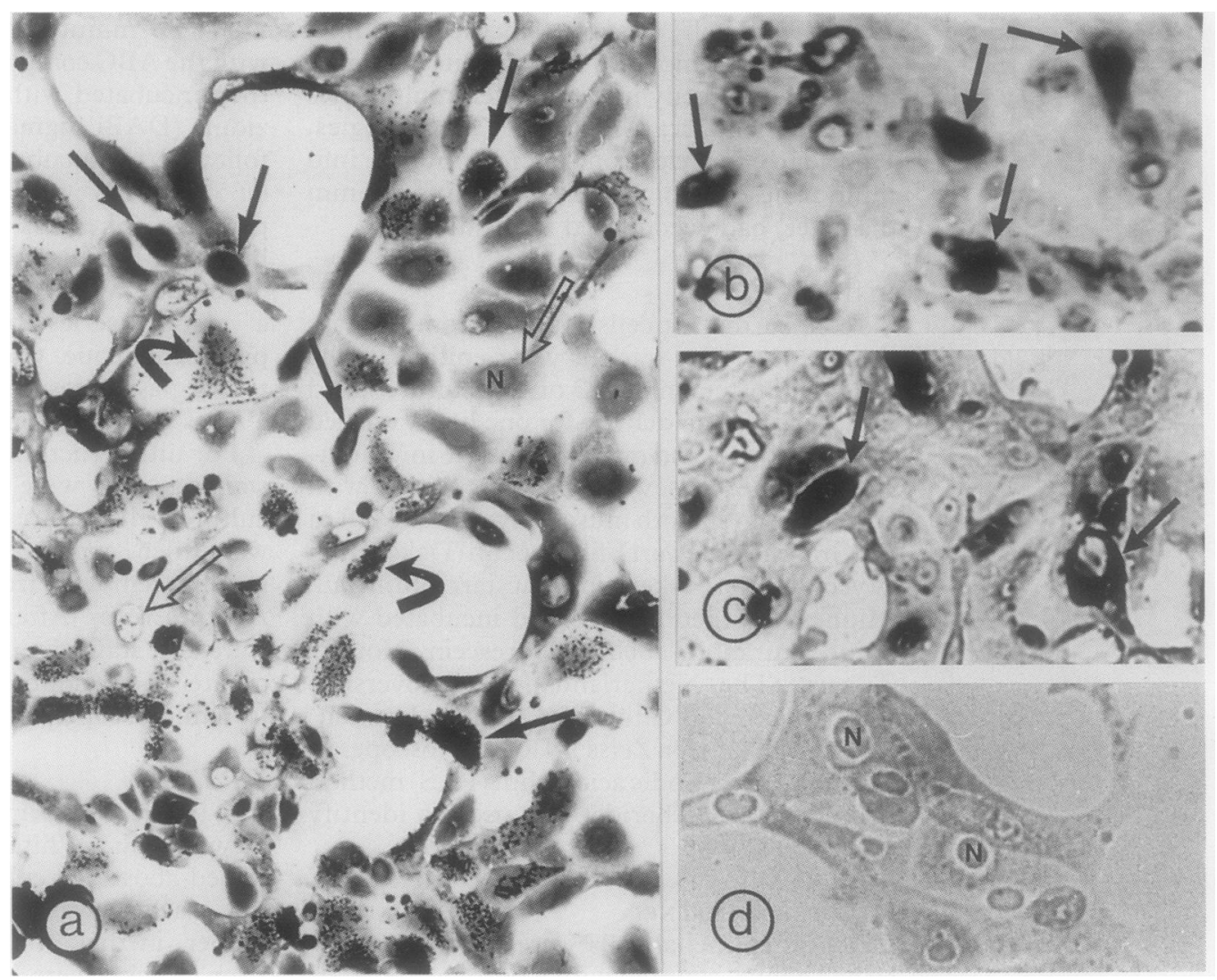

Figure 2 Light microscopy of cultured rabbit tracheal epithelial cells labelled for $E T-1(a), A V P(b)$, and substance $P(c)$. The cells display distinctive cytoplasmic staining (appearing as a dark brown stain in the original preparations), especially of the perinuclear regions (black arrows). In (a) the immunonegative cells (transparent arrows) and the cells with labelled cilia (curved arrows) are also seen; $N$-cell nucleus. Note the unlabelled cells in (d) processed for control immunocytochemistry by omission of the primary antibody step. $(a)$ and $(d)$-cells cultured on glass coverslip; (b) and (c)-cells cultured in plastic dish.

\section{Results}

CHARACTERISATION OF TRACHEAL EPITHELIAL CELLS IN CULTURE

Cells isolated from the rabbit trachea by incubation overnight with protease were harvested and seeded into culture. Approximately $2.5 \times 10^{6}$ cells may be obtained from one rabbit trachea, but this is only a rough estimate because the cells slough off from the airways in large sheets making it difficult to quantify cell numbers accurately. After two hours in culture, approximately $25 \%$ of these cells adhered to the culture dish. This increased to $29 \%$ at four hours and $35 \%$ by five hours and a maximum of $40 \%$ of cells had adhered to the plastic 24 hours after seeding. Under the phase contrast microscope, these cells appeared flattened and polyhedral in shape (fig 1), resembling the cobblestone appearance of vascular endothelium in culture. Both ciliated (approximately $37.5 \%$ ) and non-ciliated cells were present, generally with groups of two or three ciliated cells distributed among the nonciliated cells. The cilia were up to $3 \mu \mathrm{m}$ in length and continued to beat for as long as five days in culture. When fixed and stained by the PAS method for mucopolysaccharides, approximately $25 \%$ of 100 cells from each dish stained positively. Further immunofluorescent staining to characterise the epithelial nature of the isolated cells showed no fluorescence when antibodies against smooth muscle myosin and fibronectin were tested, but all cells stained strongly when incubated with antibodies to $\alpha$ keratin, a marker commonly used to identify epithelial cells.

\section{IMMUNOCYTOCHEMISTRY}

Cultured cells

When the immunohistochemical preparations were viewed under the light microscope, cells staining positively for ET-1, AVP, and SP were present in the tracheal epithelial cultures (fig $2 \mathrm{a}-\mathrm{c}$ ). No reactivity was found in controls (fig 2d). At the level of the light microscope, immunoreactivity was observed in both ciliated and non-ciliated cells. This was especially clear in cells labelled for ET-1 (fig 2a). The staining intensity of the cells positive for ET-1, AVP, and SP also varied considerably from one cell to another. The intensive staining, a brown-black cytoplasmic precipitate, was confined mainly to the central region of the cells. Interestingly, in some preparations the cilia of both positive and negative cells stained strongly (fig 2a).

Under the electron microscope the diverse nature of the isolated cells was again confirmed by the presence of ciliated, non-ciliated, and smaller cells which may be basal cells. It was found, however, that the cells staining positively for ET-1, AVP, and SP were ciliated. These positive cells had a diffuse pattern of 
Figure 3 Electron micrographs of cultured rabbit tracheal epithelial cells. (a) A fragment of an ET-1 positive cell showing immunoprecipitate in the perinuclear region of the cytoplasm and in association with cytophilia. Note unlabelled cell nucleus and nucleolus. cf-cytophilia; $\mathrm{N}$ nucleus; nu-nucleolus. (b) A fragment of cytoplasm of an AVP positive cell showing clustered

immunoprecipitate

(arrows).m-

mitochondria.

(c) An example of substance $P$ positive (white asterisk) and negative (black asterisks) cell profiles. Note the close apposition of the basal parts of the cells.

(d) An AVP negative cell (asterisk) showing cytophilia displaying surface associated $A V P$ immunoprecipitate. Note strong immunoreactivity of the material attached to the cilia profile. ci-cilia, bb-basal bodies; $p l-$ plastic from culture wells.
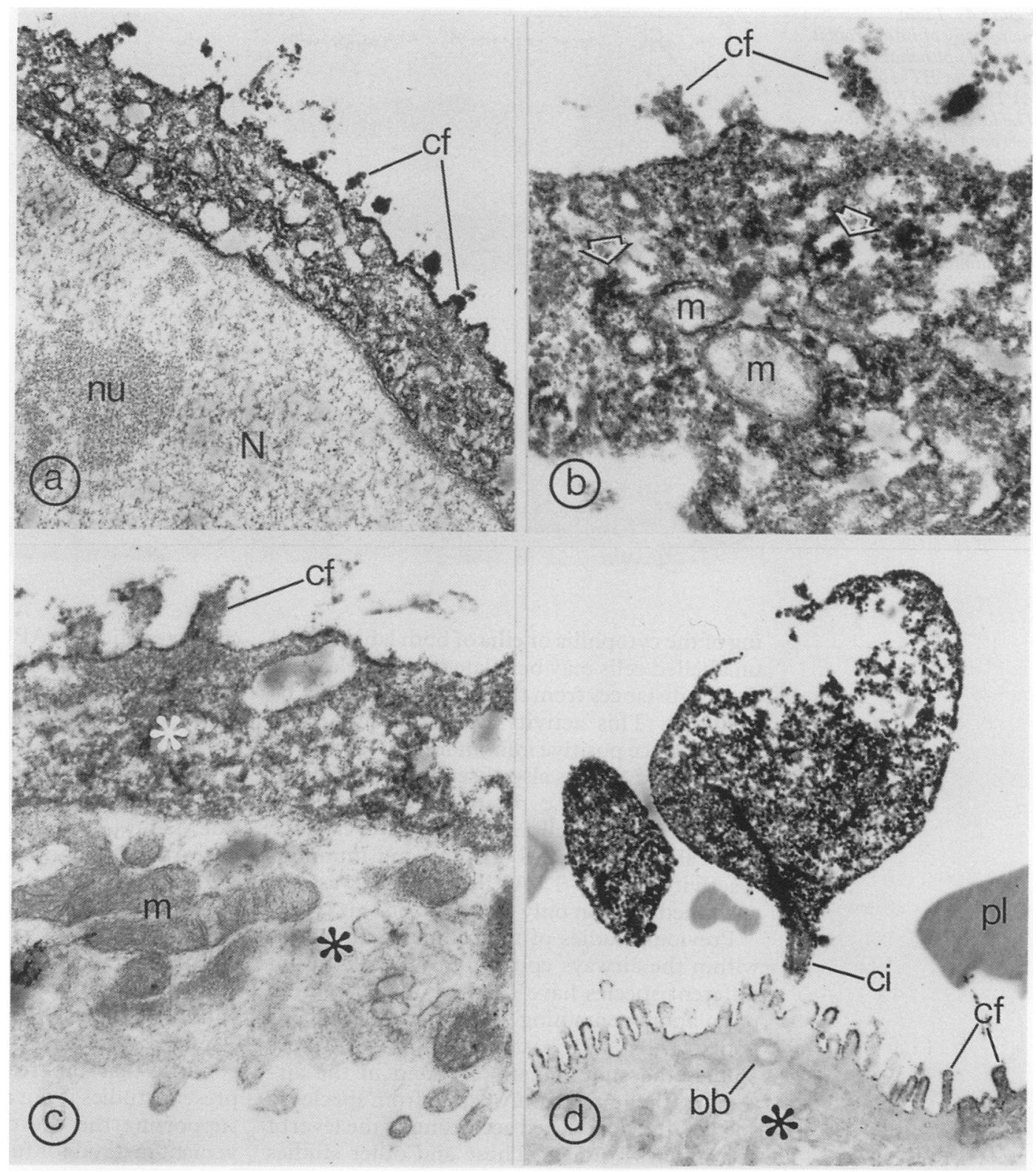

staining throughout the cytoplasm (fig 3a-c). The particles of immunoprecipitate were mostly spread throughout the whole cytoplasmic matrix without preferential labelling of particular subcellular organelles. The strong staining of the cilia, which was seen at the level of the light microscope, was seen more clearly at this level (fig 3a-c). It was also apparent that positively stained cilia were clearly associated with non-staining cells (fig 3d).

\section{Intact tissue}

Cells showing positive immunoreactivity for ET-1, AVP, and SP were scattered throughout the epithelium lining the trachea (fig 4). The positive cells were round or ovoid in shape and strong immunoreactivity was observed to ET1, AVP, and SP. The pattern of staining was similar at all levels of the trachea examined.

\section{Discussion}

This study shows that cells cultured from the tracheal epithelium react positively to antisera for ET-1, AVP, and SP. This staining is unlikely to be artefactual as the antisera used in this study were specific for the peptides under investigation and appropriate controls were included. Furthermore, ET-1 and AVP are released from tracheal epithelial cultures upon stimulation with thrombin (Rennick and Milner, unpublished observations). At the light microscope level, this reactivity of cultured epithelium was observed within both ciliated and non-ciliated cells. However, electron microscope observations of the labelled cells showed that the immunoprecipitate was present within ciliated cells exclusively. This apparent difference between light and electron microscopic findings may be due to the density and length of the cilia of these cells-that is, cells with sparse, short cilia were not clearly visible under the light microscope. There was also some variability in the intensity of staining; this may be due to variable cell spreading across the culture surface or genuine differences in storage levels between cells. In addition, the possibility that the presence of immunolabell- 
Figure 4 Light microscopy of intact rabbit tracheal epithelial cells labelled for $E T-1$ (a), $A V P(b)$, and $S P(c)$.
labelled for The labelled cell profiles (arrows) display cytoplasmic staining (appearing as a brown stain in the original preparations). Eprespiratory epithelium Lp-lamina propria; ci-cilia. Note lack of labelled cells in $(d)$, processed for control immunocytochemistry by omission of the primary antibody step.

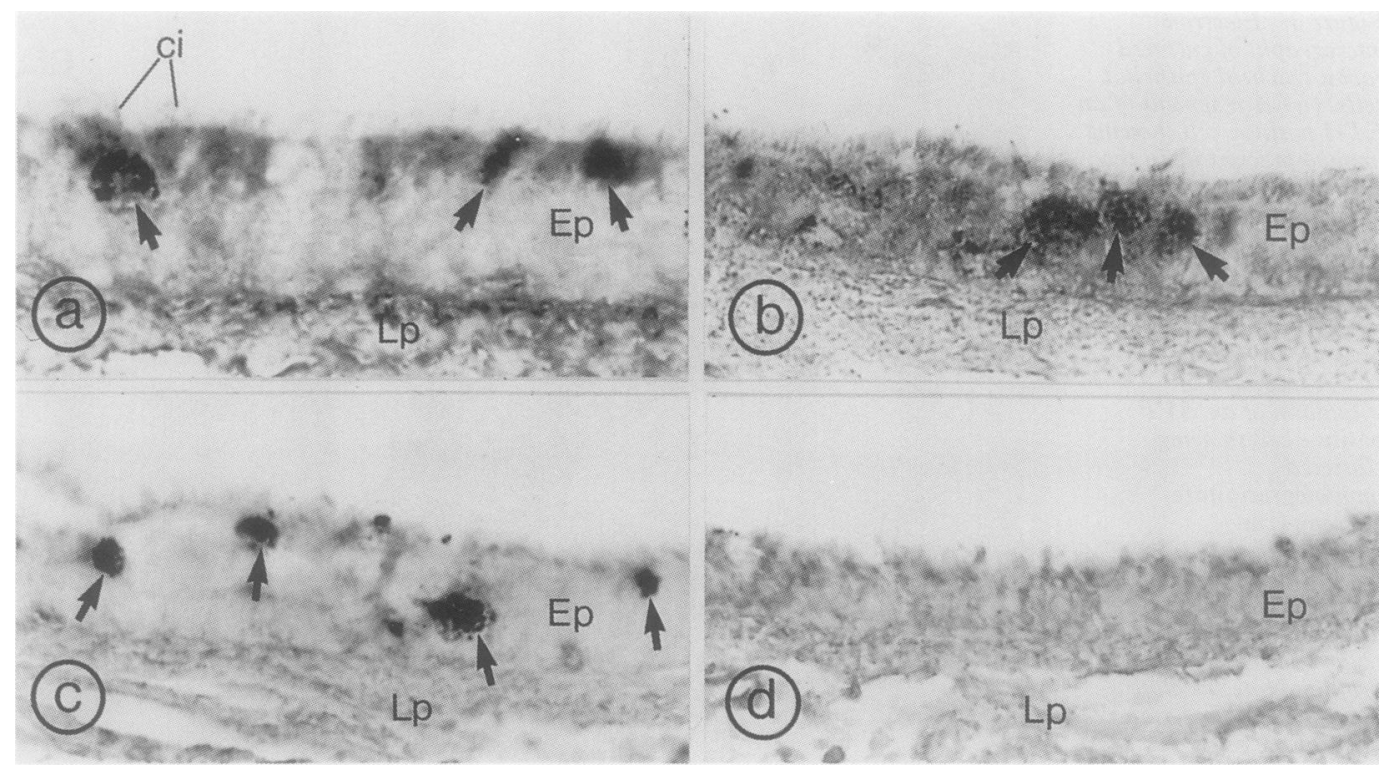

ing of the cytophilia or cilia of both labelled and unlabelled cells may be related to the release of these substances from the epithelium cannot be excluded. This activity was not confined to culture since positive immunoreactivity to ET$1, A V P$, and SP was also observed in sections of intact tissue. These positively staining cells resembled goblet cells in shape. However, since co-localisation of PAS staining and immunoreactivity to ET-1, AVP, and SP was not examined, we can only speculate on this point.

Previous studies of the cellular populations within the airways epithelium of a number of different species have shown a mixed cellular population containing ciliated cells, mucous goblet cells and basal cells. ${ }^{131521}$ In these studies the subpopulations found in the airways epithelium not only varied from species to species, but also varied according to the level of the airways studied. These and other studies have examined the airways of the rabbit and have shown a number of cellular subpopulations to be present. ${ }^{12131522}$ Of particular interest to the present study is the finding of nonciliated, elongated cells containing numerous dense core vesicles in their cytoplasm within the epithelium in sections of trachea. ${ }^{13}$ These cells occur singly in the trachea but in clusters known as neuroepithelial bodies further down the respiratory tract. The single cells of the trachea, referred to as APUD, ${ }^{12}$ Kultchisky, ${ }^{13}$ or neuroepithelial ${ }^{23}$ cells, contain polypeptides and $5-\mathrm{HT}^{15}$ within the dense core vesicles. The Kultchisky cells and their dense core vesicles were situated close to the basement membrane and it has been proposed that this localisation is indicative of a secretion being directed towards the underlying structures such as the airways muscle ${ }^{13}$ or, alternatively, nearby nerve endings. ${ }^{22}$ Indeed, the presence of these cells containing factors such as 5-HT supports the present findings that the airways epithelium contains factors which may regulate airways reactivity. However, in the present ultrastructural studies, ET-1, AVP, and SP were found in ciliated cells and were present throughout the cytoplasmic matrix-that is, the cells that stained positively for ET, AVP, and SP did not have the dense core vesicles characteristic of APUD cells described by Sonstegaard et al. ${ }^{12}$ The present findings suggest that there is some heterogeneity of the cells with respect to their immunoreactivity to ET-1, AVP, and SP rather than just a single population as reported for 5-HT. ${ }^{12}$

Previous studies have found vasoactive peptide, peptide histidine methionine, calcitonin gene related peptide, galanin, SP, neuropeptide $\mathrm{Y}$, and bombesin in association with the nerves of the respiratory tract, ${ }^{24} 25$ but more recently ET has been localised in rat bronchial epithelial cells ${ }^{26}$ as well as in human tracheal epithelial cells, ${ }^{2728}$ and SP immunoreactive endocrine like cells have been reported in the guinea pig trachea. ${ }^{29}$ These previous findings confirm that the reactivity observed in the present studies is not an artefact of cell culture, supporting the use of this system as a convenient method for further study of release and other characteristics of this mixed cellular population.

The presence of vasoactive substances such as ET-1, AVP, and SP may be of importance to airways reactivity as organ bath studies have shown that the sensitivity of airways smooth muscle to various drugs is altered when the epithelium is removed from airways preparations. ${ }^{29}$ From such pharmacological studies it has been suggested that the epithelium is the source of factors that act on the airways smooth muscle to cause relaxation. It may be possible that factors such as those identified in this study are released to the underlying smooth muscle, as well as to the lumen, thus influencing both airways reactivity and mucociliary clearance. Indeed, postmortem examination of airways from asthmatics has shown that the epithelium is altered in these subjects, ${ }^{130}$ suggesting that the normal control mechanisms which maintain airways reactivity are either removed or inactive.

Studies in this laboratory not only have localised neuropeptides in the endothelium of the intact artery wall, ${ }^{31-35}$ but also have localised and co-localised neuropeptides in cultured vascular endothelium. ${ }^{36}$ These peptides may also be released from the endothelium under conditions of fast flow and hypoxia-that is, condi- 
tions in which there is an increased vascular resistance. ${ }^{37-39}$ If the cells of the airways epithelium release these neuropeptides to maintain airways calibre, then mechanisms similar to those involved in control of vasospasm may be active in the airways.

At present it is not known whether the cells of the airways epithelium take up these neuropeptides from an exogenous source (such as mucous or other cell types), or whether the epithelium itself may synthesise the peptides. Ericson $e t a l^{40}$ have shown that 5-HT localised within APUD cells of the trachea is synthesised from exogenous amine precursors. More recent studies by Armour et al $^{41}$ suggest that the epithelium itself may synthesise the peptides. They examined autoradiographically the presence of ET-1 receptors in the trachea and found these receptors to be present on smooth muscle and parasympathetic nerves but not on the epithelium. It is also not known whether epithelial cells containing ET-1, AVP, and SP release these peptides under conditions that cause airways constriction. Such questions are currently under investigation and their answers may contribute to our understanding of airways control both in health and in disease conditions such as bronchial asthma.

R E Rennick and A Loesch are British Heart Foundation overseas visiting scientists. We would like to thank MrE Moules and Ms D Bailey for their technical assistance.

1 Laitinen LA, Heino M, Laitinen A, Kava T, Haahtela T. Damage of the airway epithelium and bronchial reactivity in patients with asthma. Am Rev Respir Dis 1985;131: 599-606.

2 Aarhus LL, Rimele TJ, Vanhoutte PM. Removal of the epithelium causes bronchial supersensitivity to acetylcholine and 5-hydroxytryptamine. Fed Proc 1984;43:955.

3 Flavahan NA, Aarhus LL, Rimele TJ, Vanhoutte PM. The respiratory epithelium inhibits bronchial smooth muscle tone. J Appl Physiol 1985;58:834-8.

4 Goldie RG, Papadimitriou JM, Paterson WJ, Rigby PJ, Self HM, Spina D. Influence of the epithelium on responsiveness of guinea-pig isolated trachea to contractile and relaxant agonists. Br J Pharmacol 1986;87:5-14.

5 Hay DWP, Farmer SG, Raeburn D, Robinson VA, Fleming WW, Fedan JS. Airway epithelium modulates the reactivity of guinea-pig respiratory smooth muscle. Eur $J$ Pharmacol 1986;129:11-8.

6 Murlas C. Effects of mucosal removal on guinea pig airway smooth muscle responsiveness. Clin Sci 1986;70:571-5.

7 Raeburn D, Hay DW, Robinson VA, Farmer SG, Fleming WW, Fedan JS. The effect of verapamil is reduced in isolated airway smooth muscle preparations lacking the epithelium. Life Sci 1986;38:809-16.

8 Raeburn D, Hay DWP, Farmer SG, Fedan JS. Epithelium removal increases the reactivity of human isolated tracheal muscle to metacholine and reduces the effect of verapamil. Eur J Pharmacol 1986;123:451-3.

9 Flavahan NA, Vanhoutte PM. The respiratory epithelium releases a smooth muscle relaxing factor. Chest 1985;87 (Suppl):189-90.

10 Furchgott RF, Zawadski JV. The obligatory role of endothelial cells in the relaxation of arterial smooth muscle by acetylcholine. Nature 1980;288:373-6.

11 Orehek J, Douglas JS, Bouhuys A. Contractile responses of the guinea pig trachea in vitro: modification by prostaglandin synthesis-inhibiting drugs. J Pharmacol Exp Ther 1975;194:554-64.

12 Sonstegaard KS, Cutz E, Wong V. Dissociation of epithelial cells from rabbit trachea and small intestine with demonstration of APUD endocrine cells. Am J Anat 1976;147: 357-74.

13 Cutz E, Chan W, Wong V, Conen PE. Ultrastructure and fluorescence histochemistry of endocrine (APUD-type) cells in tracheal mucosa of human and various animal species. Cell Tissue Res 1975;158:425-37.

14 Lauweryns JM, de Bock V, Verhofstad AAJ, Steinbusch HWM. Immunohistochemical localisation of serotonin in intrapulmonary neuro-epithelial bodies. Cell Tissue Res 1982;226:215-23.

15 Dey RD, Echt R, Dinerstein RJ. Morphology, histo- chemistry and distribution of serotonin-containing celils in tracheal epithelium of adult rabbit. Anat Rec 1981;199: 23-31.

16 Wu R, Smith D. Continuous multiplication of rabbit tracheal epithelial cells in a defined, hormone-supplement medium. In Vitro 1982;18:800-12.

17 Drury RAB, Wallington EA. Carleton's histological technique. 4th edn. London: Oxford University Press, 1973: 204-7.

18 Lowry CH, Rosebrough NH, Farr AL, Randall RJ. Protein measurement with the Folin phenol reagent. J Biol Chem 1951;193:265-75.

19 McLean IW, Nakane PK. Periodate-lysine-paraformaldehyde fixation. A new fixative for immuno-electron microscopy. J Histochem Cytochem 1974;22:1077-83.

$20 \mathrm{Hsu}$ S, Raine L, Fanger H. Use of avidin-biotin-peroxidase complex $(\mathrm{ABC})$ in immunoperoxidase technique: a comparison between $\mathrm{ABC}$ and unlabelled antibody (PAP) procedures. J Histochem Cytochem 1981;29:577-80.

21 Plopper CG, Heidsiek JG, Weir AJ, St George JA, Hyde DM. Tracheobronchial epithelium in the adult rhesus monkey: a quantitative histochemical and ultrastructural study. Am J Anat 1989;184:31-40.

22 Echt R, Ross LM, Roth RA, Pearsall AD. The effects of carbon monoxide and hypoxic hypoxia on amine-containing cells in the tracheal epithelium of young rabbits. Cell Tissue Res 1982;224:129-35.

23 Lauweryns JM, Peuskins JC. Argyrophil (kinin and amine producing?) cells in human infant airway epithelium. Life Sci 1969;8:577-85.

24 Aghatei M, Springall DR, Richards IM, Oostveen JA, Griffin RL, Cadieux A, et al. Regulatory peptides in the respiratory tract of Macaca fascicularis. Thorax 1987;42: 431-9.

25 Laitinen LA, Laitinen A, Panula PA, Partanen M, Tervo K, Tervo T. Immunohistochemical demonstration of substance $P$ in the lower respiratory tract of the rabbit and not of man. Thorax 1983;38:531-6.

26 Nomura A, Uchida $Y$, Ishii $Y$, Kameyama M, Ninomaya $H$, Saotome M, et al. Endothelin, a bronchosconstrictor, is located in rat bronchial epithelial cells. Am Rev Respir Dis 1990;141:A290.

27 Springall DR, Howarth PH, Counihan H, Djukanovic R, Holgate ST, Polak JM. Endothelin immunoreactivity of airway epithelium in asthmatic patients. Lancet 1991;337: 697-701.

28 Black PN, Ghatei K, Takahashi D, Bretherton-Watt T, Krausz T., Dollery CY, et al. Formation of endothelin by cultured airway epithelial cells. FEBS Lett 1989;255:129.

29 Nilsson G, Dahlberg K, Brodin E, Sundler F, Strandberg K. Distribution and constrictor effect of substance $P$ in guinea pig tracheobronchial tissue. In: von Euler US, Pernow B, eds. Substance P. New York: Raven Press, 1977:75-81.

30 Dunnill MS. The pathology of asthma, with special reference to changes in the bronchial mucosa. J Clin Pathol Lond 1960;13:27-33.

31 Burnstock G, Lincoln J, Fehér E, Hopwood AM, Kirkpatrick K, Milner P, et al. Serotonin is localized in endothelial cells of coronary arteries and released during hypoxia: a possible new mechanism for hypoxia-induced vasodilatation of the rat heart. Experientia 1988;44:705-7.

32 Loesch A, Burnstock G. Ultrastructural localisation of serotonin and substance $P$ in vascular endothelial cells of rat femoral and mesenteric arteries. Anat Embryol 1988; 178:137-42.

33 Lincoln J, Loesch A, Burnstock G. Localization of vasopressin, serotonin and angiotensin II in endothelial cells of the renal and mesenteric arteries of the rat. Cell Tissue Res 1990;259:341-4.

34 Loesch A, Tomlinson A, Burnstock G. Localization of arginine-vasopressin in endothelial cells of rat pulmonary artery. Anat Embryol 1991;183:129-34.

35 Tomlinson A, Van Vlijman H, Loesch A, Burnstock G. An immunocytochemical study of endothelial cell heterogeneity in the rat: observations in "en face" Häutchen preparations. Cell Tissue Res 1991;263:173-81.

36 Loesch A, Bodin P, Burnstock G. Colocalization of endothelin, vasopressin and serotonin in cultured endothelial cells of rabbit aorta. Peptides 1991;12:1095-103.

37 Milner P, Ralevic V, Hopwood AM, Fehér E, Lincoln J, Kirkpatrick KA, et al. Ultrastructural localisation of substance $\mathbf{P}$ and choline acetyltransferase in endothelia cells of rat coronary artery and release of substance $P$ and acetylcholine during hypoxia. Experientia 1989;45:121-5.

38 Milner P, Bodin P, Loesch A, Burnstock G. Rapid release of endothelin and ATP from isolated aortic endothelial cells exposed to increased flow. Biochem Biophys Res Commun 1990;1 170:649-56.

39 Ralevic V, Milner P, Hudlická O, Kristek F, Burnstock G Substance $P$ is released from the endothelium of norma and capsaicin-treated rat hindlimb vasculature, in vivo, by increased flow. Circ Res 1990;66:1178-83.

40 Ericson LE, Häkäson R, Larson B, Ovman CK, Sundler F. Fluorescence and electron microscopy of amine-storing enterochromaffin-like cells in tracheal epithelium of mouse. Z Zellforsch 1972;124:532-45.

41 Armour CL, McKay KO, Diment LM, Black JL. Endothelin-functional and autoradiographic studies in human airways. Eur J Pharmacol 1990;183:183. 